UDC: $061.22(=161.2):(437.7) “ 1938 / 1939 “$

050.9(=161.2):(437.7)“1938/1939““

Јанко Ђ. Рамач

Универзитет у Новом Саду

Филозофски факултет

Одсек за русинистику
Оригиналан научни рад

примљено: 30. март 2013

прихваћено: 1. октобар 2013

\title{
РУСИНСКО НАРОДНО ПРОСВЕТНО ДРУШТВО И РЕЦЕПЦИЈА О ПОТКАРПАТСКОЈ РУСИЈИ/КАРПАТСКОЈ УКРАЈИНИ У ЊЕГОВИМ ИЗДАЫИМА 1938-1939. ГОДИНЕ
}

Сажетак: Чехословачка је тек 1938. године, у време политичке кризе због Судетске области и Минхенског споразума, показивала спремност да Поткарпатској Русији да аутономију у складу са Сенжерменским уговором из 1919. године. У издањима Русинског народног просветног друштва, нарочито у недељним новинама Руски новини (Русинске новине) помно су праћени догађаји у Поткарпатској Русији од стицања суштинске аутономије до проглашења независне државе Карпатске Украјине и њене пропасти. У овом раду биће приказане вести, прилози, коментари и чланци о Поткарпатској Русији / Карпатској Украјини у издањима Русинског народног просветног друштва и сагледани њихово значење и утицај у културно-националном животу Русина у Југославији 1938-1939. године.

Кључне речи: Чехословачка, Поткарпатска Русија / Карпатска Украјина, Русини, Украјинци, Русинско народно просветно друштво, Руски новини, Августин Волошин.

Русинско народно просветно друштво (даље: РНПД) од свог оснивања 1919. године настојало је да одржава везе и контакте Русина у Краљевини СХС/Југославији са Русинима/Украјинцима у старом завичају, у Чехословачкој, Мађарској и Пољској. У издањима РНПД, у русинским календарима - Руски календар ${ }^{1}$ (даље: РК) и у недељним новинама Руски новини ${ }^{2}$ (даље: РН) објављиване су вести, прилози, коментари и чланци о Русинима/Украјинцима у овим државама. ${ }^{3}$

\footnotetext{
* Текст је настао као фазни резултат на пројекту Војвођански простор у контексту европске историје (бр. 177002) Министарства просвете и науке Републике Србије.

${ }^{1}$ Руски календар (1921-1941) - годишња публикација РНПД, штампана у тиражу 2.500-3.000 примерака, тако да је био присутан у скоро свакој русинској кући у Краљевини СХС/Југославији.

${ }^{2}$ Руски новини (1924-1941) - недељне новине, огран РНПД.

${ }^{3}$ Ова тема је већ била дотакнута у два прилога: у публицистичком раду у ком су само наведени неки прилози из РН и РК о догађајима у Поткарпатској Русији / Карпатској Украјини (Паплацко 1995), и у прилогу који приказује поетска дела Русина и Украјинаца у Југославији о Карпатској Украјини (Цап 1995).
} 
На Мировној конференцији у Паризу 1918. године разматрано је питање Русина који су до 1918. године живели у североисточној Угарској, а коначна одлука о њиховој будућности није била у складу са прокламованим принцима права народа на самоопредељење, већ у интересу Чехословачке и сила Антанте да новостворене државе буду снажна баријера која ће штитити Централну и Западну Европу од руског бољшевизма. ${ }^{4}$

Према Мировном уговору у Сен Жермену потписаном 10. септембра 1919. године између сила Антанте и Чехословачке, територија јужно од Карпата насељена Русинима прикључена је Чехословачкој републици. Одредбе Мировног уговора (параграфи 10-13) односе се на гаранције аутономних права и стварале су основу за државноправне односе између Поткарпатске Русије ${ }^{5}$ и Чехословачке републике, којима се Чехословачка обавезала да ће признати русинску територију јужно од Карпата, чије границе ће одредити представници савезника и других држава. Ова област ће бити као административна јединица у саставу Чехословачке државе, која ће јој дати најширу самоуправу у складу са јединством државе (§ 10); ова русинска територија јужно од Карпата имаће свој парламент (сојм), који ће имати законодавну власт у питањима језика, школства, религије, а такође и у питањима локалне власти и у свим другим питањима, која одреде чехословачки закони. Председник државе ће постављати губернатора русинске територије који ће бити одговоран русинском сојму (§ 11); Чехословачка се слаже да чиновнике на русинској територији по могућности постављају становници ове територије (§ 12); Чехословачка гарантује територији Русина праведно представништво у парламенту Чехословачке републике, које ће бити бирано у складу са уставом државе. Ипак, ови посланици у чехословачком парламенту неће имати право гласа у законодавним питањима која улазе у компетенцију русинског парламента (§ 13).

Чехословачка је дуго упорно одбијала да Поткарпатској Русији да обећану аутономију, па је она постојала више на папиру и у обећањима, него у стварности. Без обзира на то колико су се Русини и до тада борили за своју аутономију, међународне прилике у великој мери допринеле су и убрзале тај процес, нарочито победа нацизма у Немачкој и настојање Берлина да се сви Немци уједине у оквиру једне државе. Судетска криза 1938. године допринела је радикализацији словачких и русинских захтева, нарочито после Минхенске конференције, када је Немачка остварила своје захтеве према Судетској области. Под притиском ревизионистичких

\footnotetext{
${ }^{4}$ Іван Ванат, Нариси новітньої історії українців Східної Словаччини I (1918-1938), Пряшів 1990, 408.

5 У Уставу Чехословачке републике територија јужно од Карпата насељена Русинима добија назив Поткарпатска Рус (на чешком и словачком: Potkarpatská Rus, на украјинском - Підкарпатська Русь), а у српској историографији присутнија је под именом Поткарпатска Русија. Од новембра 1938. године поред имена Поткарпатска Русија користи се и име Карпатска Украјина, које ће од 1. јануара 1939. године постати званично.

${ }^{6}$ I. Ванат, Нариси новітньої історії украӥнців Східної Словаччини I (1918-1938), 84; Вікентій Шандор, Спомини, т. I, Гражда, Ужгород 1996, 43.
} 
захтева нацистичке Немачке и Мађарске, власти Чехословачке показале су спремност да Словачкој и Поткарпатској Русији дају суштинску аутономију. Праг више није могао да одлаже захтеве Русина који су имали снажну међународноправну основу за гарантовани аутономни статус у Сенжерменском уговору. ${ }^{7}$

У периоду између два светска рата међу Русинима у Чехословачкој постојале су три националне струје: проруска (русофилска), русинско-украјинска и промађарска. Чешка влада је у политичком и културно-националном животу Русина/Украјинаца у Поткарпатској Рујсији углавном подржавала проруску струју и тако је успевала да осујети формирање јединственог русинско-украјинског фронта.

У другој половини 30-их година у Поткарпатској Русији друштвенополитички живот се радикализује у односу према питањима културно-националног живота Русина/Украјинаца и остваривања суштинских аутономних права. Без обзира на међусобне разлике, често и потпуно супротстављене ставове о питањима културно-националног идентитета и развоја Русина/Украјинаца, водеће политичке партије у Поткарпатској Русији почеле су да траже платформу за заједнички наступ пред чешким властима. У првој половини 1938. године формира се јединствени фронт за преговоре са владом у Прагу и то је донело прве успехе на том плану. Крајем маја одржана је седница Првог русинско/украјинског централног народног већа, на којој је потврђен стари захтев да се распишу избори за парламент Поткарпатске Русије и да јој се присаједини територија источне Словачке коју у већини насељавају Русини/Украјинци. ${ }^{8}$ У $\mathrm{PH}$ се наводи да су после тога Августин Волошин ${ }^{9}$ и Јулијан Ревај ${ }^{10}$ отпутовали у Праг и изнели чешкој влади захтеве у шест тачака: да у влади у Прагу буде један министар за Поткарпатску Русију; да сва управа у Поткарпатској Русији буде у власти русинског губернатора; да са државним иметком Поткарпатске Русије управљају Русини, а не Чеси; да у Ужгороду постоји посебно министарство образовања; да се у Поткарпатској Русији затворе чешке школе које немају прописан број ученика; да у свим уредима у Поткарпатској Русији буде најмање $60 \%$ Русина. $^{11}$

Од лета 1938. године политички догађаји у Поткарпатској Русији добијали су све више простора у РН, нарочито од почетка издавања дневних новина Нова свобод $a,{ }^{12}$ из којих су најчешће преузимане вести, јер су руководству РНПД биле

\footnotetext{
${ }^{7}$ Василь Маркусь, Еволючія політично-правового статусу Карпатської Украӥни в $1938-1939$ роках, Карпатська Україна і Августин Волошин, (Матеріали міжнародної наукової конференції "Карпатська Україна - пролог відродження української держави” (Ужгород, 11-12 березня 1994), Ужгород 1995, 9-13.

8 Павло Роберт Магочій, Формування національної самосвідомості: Підкарпатська Русь (1848-1949), Ужгород 1994, 142-143.

9 Августин Волошин (1874-1945) - гркокатолички свештеник, педагог, истакнути културно-политички и национални делатник проукрајинске оријентације, од октобра 1938. године премијер-министар кабинета Поткарпатске Русије, 15. марта 1939. изабран за првог председника Карпатске Украјине.

10 Јулијан Ревај (1889-1979) - један од најпопуларнијих делатника проукрајинске оријентације у Поткарпатској Русији / Карпатској Украјини. Био је члан чешког парламента, министар у неколико кабинета Поткарпатске Русије и министар спољних послова Карпатске Украјине.

${ }^{11}$ Руски новини, 27/1938, 8. јул, 1; 28/1938, 15. јул, 1.

${ }^{12}$ Нова свобода (15. јун 1938 - 15. март 1939) - дневне новине које су излазиле прво у Ужгороду, после у Хусту.
} 
блиски културно-национални и идеолошки ставови уредништва тих новина. У јулу 1938. године у РН објављен је текст под насловом „Русини на Горнїци и Чехи““13 према чланку из новина Нова свобода. У тексту се говори о односу чешких власти према Русинима у Чехословачкој. Признаје се да су Русини у чехословачкој држави постигли значајне резултате у привредном и друштвеном погледу, али се указује и на грешке чешке владе које је правила према Русинима, а последице тих грешака често вешто користе непријатељи државе и Русина. Једна од тих грешака је да су централне власти у администрацију и у све државне службе у Поткарпатској Русији углавном доводиле и постављале Чехе, који нису знали русински језик нити су познавали локалне прилике, а образовани Русини нису могли да добију посао. Још веће грешке чешка влада је направила у области русинског школства, јер није дозволила да се у школама учи на русинском језику, већ је увођен вештачки језик, стваран уз помоћ руских емиграната, којим нико не говори и који нико не разуме. Влади се замера да су чешке школе отваране свуда где је било само неколико чешке или јеврејске деце. На крају се истиче да Русини захтевају да се такво стање из темеља промени и да hе се они снажно борити против оваквих метода свог однарођивања и да неће дозволити да се крше њихова права, јер желе да буду господари на својој земљи. Признаје се да међу Русинима има доста оних који су се „продали“ Чесима и свесно праве раздор међу Русинима, али, без обзира на све, народни покрет постаје све снажнији. ${ }^{14}$ Овакви текстови су Русинима у Југославији давали добру информацију о приликама у којима су живели њихови сународници у Чехословачкој, а истовремено су им указивали да националне мањине без добре организације и упорне борбе не могу да остваре своја национална права и да се одупру асимилацији.

У лето 1938. године проукрајинска оријентација у политичком животу Поткарпатске Русије постајала је све доминантнија, што показују и конкретни подаци о националном опредељењу учитеља. Учитељско друштво у Поткарпатској Русији имало је укупно 2.300 чланова учитеља, а 1.630 од њих били су проукрајинске оријентације. На свом конгресу одржаном од 2. до 4. јула 1938. године учитељи су протестовали против увођења у русинске школе руских књига, које деца не разумеју, и истицали су да су Русини део украјинског народа. ${ }^{15}$

На скупштини Првог русинско-украјинског централног народног већа у Ужгороду 4. септембра, које је окупљало партије проукрајинске оријентације, донета је одлука да се захтева од владе у Прагу аутономија Поткарпатске Русије у складу са Сенжерменским уговором из 1919. године и чехословачким уставом. ${ }^{16}$ у РН се наводи да је 3. септембра у Ужгороду организован протестни скуп против чешке политике фаворизовања русофила и против насилног увођења руског језика у русинске школе. ${ }^{17}$ Делегација Првог русинско-украјинског централног народног

\footnotetext{
${ }^{13}$ Горнїца - Горња земља, Горњи крај - тако су Русини у Јужној Угарској / Југославији називали североисточне области Угарске, свој стари завичај. Овде се мисли на Поткарпатску Русију.

${ }^{14}$ Руски новини, 26/1938, 1. јул, 1.

${ }^{15}$ Руски новини, 28/1938, 15. јул, 1.

${ }^{16}$ І. Ванат, Нариси новітньої історії украӥнців Східної Словаччини II (1938-1948), Пряшів 1985, 12.

${ }^{17}$ Руски новини, 36/1938, 9. септембар.
} 
већа на челу са А. Волошином отпутовала је 7. септембра у Праг са захтевом да се одмах успостави пуна аутономија Поткарпатске Русије и да јој се прикључи територија источне Словачке на којој Русини чине већину. ${ }^{18}$ Ова делегација је водила преговоре са представницима чехословачке владе у канцеларији председника републике 7. и 12. септембра. ${ }^{19}$ Став Првог русинско-украјинског централног народног већа о јединству закарпатских Украјинаца са већином украјинског народа који живи с оне стране Карпата и настојање да се украјинско питање решава у свим западноукрајинским земљама, изазвали су велико незадовољство пољске и мађарске владе, које су у јачању украјинске националне идеје виделе опасност за своје државне интересе. ${ }^{20}$

Средином септембра политичка криза у Чехословачкој се заоштрава због све снажнијег захтева Немачке за присаједињене Судетске области и добија међународни карактер. У таквој ситуацији Словачка и Поткарпатска Русија виделе су своје шансе да стекну аутономију у оквиру чехословачке државе. У Ужгороду се 20. септембра састало Русинско народно веће и донело одлуку да Русини траже за себе право на самоопредељење, ${ }^{21}$ а следећег дана чехословачкој влади уручена је декларација с тим захтевом и то је требало да покаже чешкој влади јединствен став и акцију оба политичка блока - проруског и проукрајинског. ${ }^{22}$

Наредних дана политичка ситуација у Чехословачкој се мењала великом брзином. Председник Едвард Бенеш је 5. октобра поднео оставку. Словачки лидери окупљени у Жилини 6. октобра захтевали су аутономију за Словачку, а 7. октобра монсињор Јозеф Тисо постављен је за премијера аутономне Словачке. На заједничкој скупштини представника оба русинска већа, проруске и проукрајинсек оријентације, у Ужгороду 8. октобра одлучено је да се од Прага тражи за Поткарпатску Русију иста аутономија какву је добила Словачка. ${ }^{23}$ У РН наводи се да је непосредно пре Бенешове оставке промењена влада Чехословачке, у коју су ушли као министар за Словачку Ј. Тисо, а за Поткарпатску Русију Иван Паркањ, за ког се каже да је потпуно непозната личност у јавном животу Русина у Поткарпатској Русији. Због тога се констатује да су Чеси поново изиграли Русине, јер су на тако важну функцију поставили свог човека, а не неког политичког лидера који стварно представља Русине. ${ }^{24}$

Минхенским споразумом Чехословачка је морала да уступи Немачкој Судетску област, а проблем мађарске и пољске мањине у Чехословачкој требало је да се реши директним чехословачко-пољским и чехословачко-мађарским преговорима у року од три месеца. Анонимни уводничар у РН описује политичке прилике у Чехословачкој у вези са Судетском кризом и одлукама Минхенске конференције и закључује да је прошла опасност од рата. Чехословачка је јако ослабљена, јер мора

\footnotetext{
${ }^{18}$ Руски новини, 37/1938, 16. септембар.

${ }^{19}$ I. Ванат, Нариси новітньої історї̈ украӥнців Східної Словаччини II (1938-1948), 12.

${ }^{20}$ Исто, 13.

${ }^{21}$ Руски новини, 39/1938, 30. септембар, 1.

${ }^{22}$ I. Ванат, Нариси новітньої історії украйнців Східної Словаччини II (1938-1948), 15.

${ }^{23}$ П. Р. Магочій, Нав. дело, 144.

${ }^{24}$ Руски новини, 40/1938, 7. октобар.
} 
да преда Немачкој развијену и богату Судетску област са преко три милиона становника, а Мађарској треба да уступи територију са око милион становника. Аутор признаје да је то велики губитак за Чехословачку, али сматра да ће после свега Чехословачка бити чисто словенска држава, у којој ће живети три братска народа: 8 милиона Чеха, 3 милиона Словака и 700.000 Русина, и ако Чеси признају Словацима и Русинима пуну аутономију, како су обећали, држава ће бити много снажнија, јер ће сви њени грађани бити задовољни и искрено ће волети и бранити своју земљу.

После Минхенског споразума интензивирани су преговори између чешке владе и представника Поткарпатске Русије, а 11. октобра формиран је кабинет владе Поткарпатске Русије на челу са Андријем Бродијем. ${ }^{26}$ У уводнику РН од 14 . октобра анонимни аутор наводи да су Русини у Чехословачкој коначно добили своју слободу после двадесетогодишњег одбијања чехословачке владе да Русинима у Поткарпатској Русији да аутономију која им је била гарантована међународним уговором из 1919. године. У том периоду централне власти су за службенике по државним установама, на железници, по судовима и за учитеље по школама у Поткарпатској Русији постављале Чехе из чешких земаља, а образовани Русини су били без посла. Чесима се такође замера да је око 200.000 Русина остало у оквиру Словачке, мада је било обећано да ће и они ући у састав Поткарпатске Русије. Властима Чехословачке се замера и то да су Русине увек вештачки делиле и да су фаворизовале малобројнију москофилску струју у односу на народну русинску. Даље аутор даје доста интересантних статистичких података о становништву Поткарпатске Русије и наводи да је она према попису Чехословачке из 1930. године имала 720.000 становника, од тога 445.000 Русина. Дају се и подаци о службеницима, трговцима, радницима на железници и у поштама. Наводи се да од укупно 2.820 учитеља Русина има 1.418. На крају, иако изражава задовољство чињеницом да је Поткарпатска Русија добила аутономију, аутор замера чешкој влади да је 4. октобра за министра постављен Иван Паркањи, потпуно непозната личност у јавном животу Русина, као и да је прва влада Поткарпатске Русије формирана према неким интересима чешке владе, јер у њој већину чине министри проруске оријентације, мада је у политичком животу Поткарпатске Русије народна, односно русинско-украјинска струја утицајнија. ${ }^{27}$

У чланку у РН под насловом „Подкарпатска Русь шлєбодна“, уредник М. Фирак доста наивно приказује нове прилике у Чехословачкој после проглашења аутономије Словачке и Поткарпатске Русије, сматрајући да ће убудуће постојати чешко-словачко-русинска република као савезна држава, састављена од три слободне државе: чешке, словачке и русинске, и да ће свака од њих имати потпуно иста права на својој територији. Централна државна влада ће имати само три министарства: војске, финансија и иностраних послова. По њему, Чехословачка ће

\footnotetext{
${ }^{25}$ Исто, 1.

${ }^{26}$ І. Ванат, Нариси новітньої історії українців Східної Словаччини II (1938-1948), 27-27; В. Маркусь, Нав. дело, 42-43.

${ }^{27}$ Руски новини, 41/1938, 14. октобар.
} 
бити слична Швајцарској федерацији, а умногоме и некадашњој Аустро-Угарској. Даље наводи да је после дужег погађања између русинских партија 11. октобра формирана влада Поткарпатске Русије од 4 члана, са Андрејем Бродијем на челу, и са два државна секретара. Нова влада се представила народу на свечаности у Ужгороду 12. октобра. У поздравном говору министар Ј. Ревај обратио се окупљеном народу са „Украјинци и Украјинке“. Свуда су истицане плаво-жуте украјинске националне заставе. Као приоритет нове владе наводи се неопходност да се у уреде уместо Чеха и Јевреја поставе службеници Русини, да се уместо чешких за русинску децу уведу русинске школе, да се за сиромашне обезбеди храна. У том погледу влада је већ наручила из Краљевине Југославије 130 вагона кукуруза. Аутор чланка сматра да је најважније да влада Поткарпатске Русије постигне договор са Словачком да се

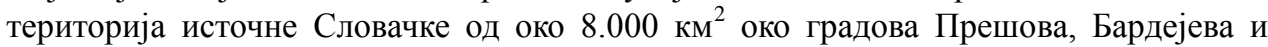
Михајловаца са око 200.000 становника, где у већини живе Русини, прикључи Поткарпатској Русији. ${ }^{28}$

Начин на који се презентују догађаји и расположење народа наводи на закључак да је аутор овог чланка преузимао податке и ставове из проукрајински оријентисане Нове свободе. Из наведеног текста се види да русински лидери нису имали довољно политичког искуства и наивно су веровали да ће лако остварити своје територијалне захтеве према Словачкој и успешно решити крупне економске проблеме и отворена политичка питања са суседима - Мађарском и Пољском. Сурова реалност брзо је прекинула почетно одушевљење које је настало добијањем аутономије. Уместо да јој буду прикључене територије источне Словачке на којој су у већини живели Русини, Поткарпатска Русија је морала да прогута горку пилулу и да уступити део властите територије Мађарској. На почетку новембра у РН на насловној страни објављена је вест под насловом „Смертельна рана Карпаторускей держави“ у којој се наводи да је Бечком арбитражом од 2. новембра одређена нова граница Мађарске са Словачком и Поткарпатском Русијом и оне су приморане да део својих територија уступе Мађарској. Поткарпатска Русија морала је да успути Мађарској градове Ужгород и Мукачево са широм околином и са око 100.000 Русина. ${ }^{29}$

У нестабилним политичким приликама у Чехословачкој и због међусобног неповерења и сукобљавања лидера русофилске и проукрајинске оријентације влада Поткарпатске Русије била је нестабилна, а власти у Прагу су често мењале њен састав. Само две недеље после постављања на место председника владе Поткарпатске Русије А. Бродиј је био смењен 26. октобра због оптужбе за велеиздају у сарадњи са Мађарима и ухапшен, а за премијера постављен је А. Волошин. У РН се наводи да је ова промена на челу владе Поткарпатске Русије у Ужгороду поздрављена одушевљеном манифестацијом уз учешће око 10.000 људи. Тада је у Поткарпатској Русији као државни уведен украјински језик, али је у службеној

\footnotetext{
${ }^{28}$ Руски новини, 42/1938, 21. октобар, 2.

${ }^{29}$ Руски новини, 44/1938, 4 новембар, 1; Ипак, у новинама није наведен тачан податак, а тачне податке даје: П. Р. Магочій, Нав. дело, 240: према одлукама Бечке арбитраже Поткарпатска Русија морала је да уступи Мађарској територију од 1.523 км² $^{2}$ са укупно 172.233 становника (према попису из 1930. године), од тога 36.735 Русина.
} 
употреби остао и руски језик. ${ }^{30}$ На насловној страни РН од 28. октобра објављене су фотографије премијера А. Волошина и министра J. Реваја, а испод њих се преноси део текста из београдских новина Време од 20. октобра под насловом „Подкарпатска Русь и Україна“ и „Подкарпатска Русь - Пиємонт Велькей України“. У тексту се наводи да је питање Поткарпатске Русије најкрупније питање европске политике, јер није реч само о 700.000 становника у заосталој Поткарпатској Русији него о високој политици, о решавању неких политичких планова, о питањима садашњости и о далекој будућности. Ту се наводи да А. Волошин већ 10 година у јавности говори о тешком положају Украјинаца у Пољској, због тога она не жели да види самосталну Поткарпатску Русију и подржава Мађарску да је присаједини и да Пољска и Мађарска добију заједничку границу. Тако Поткарпатска Русија више не би била „претња“ Пољској, јер не би подстицала националне тежње Украјинаца у Пољској. Истовремено, приближавање Пољске и Мађарске помогло би Пољској у остварењу њеног вековног плана: „Пољска од мора до мора“, и стварање неутралне територије између Немачке и Русије. ${ }^{31}$

У РН од 4. новембра објављен је преко целе стране текст „Шлєбодна Карпаторусинска держава“. У тексту се прво даје опис земље, а после следи статистика становништва, статистика привредног живота и састав владе. Анонимни аутор наводи да су лидери проруске оријентације А. Бродиј, С. Фенцик и И. Паркањи, када су дошли на највише положаје у Поткарпатској Русији, показали да се иза њиховог русофилства крије промађарска оријентација и због тога су били оптужени и смењени. Аутор оцењује да је А. Волошин донео праву одлуку када је забранио делатност свих политичких странака, јер су неки челници странака били у вези са другим владама, а дозволио је деловање само једне политичке организације Русинско-украјинског народног већа. 32 Забраном деловања свих политичких партија, осим владине, влада А. Волошина је јасно показала природу свог ауторитарног режима, што се и могло очекивати од нових влада Словачке и Поткарпатске Русије које су се наслањале на Немачку.

Уредништво РН настојало је да објављивањем прилога о Поткарпатској Русији упозна Русине у Југославији са животом и политичким тежњама њихових сународника у Чехословачкој, и да на тај начин буди и јача њихову свест о припадности великом русинско-украјинском народу. Истовремено, у Русинским новинама током 1938. године с истим циљем објављивани су и други прилози из историје Русина на Закарпатју и из историје украјинског народа. ${ }^{33}$

У време бурних догађаја у Чехословачкој и у Поткарпатској Русији у РН објављивани су и аналитички чланци у којима су аутори настојали да поред објављивања вести и описа појединих догађаја прикажу и шири политички контекст или историјат и ток неких историјских процеса. Михајло Ковач у уводнику „Єден апел“ у основним цртама описује „вековну“ политику Мађара према Русинима у

\footnotetext{
${ }^{30}$ Руски новини, 43/1938, 28. октобар, 1.

${ }^{31}$ Руски новини, 42/1938, 28. окбобар, 1.

${ }_{32}$ Руски новини, 44/1938, 4. новембар, 3.

33 У РН од јанура до аугуста 1938. објављивани су прилози из историје Кијевске Русије и Галичковолињске кнежевине, а од новембра 1938. године објављивани су прилози из историје Карпатских Русина.
} 
настојању да их асимилују. На крају наводи да је према одлукама Бечке арбитраже Поткарпатска Русија морала да уступи Мађарској део своје територије, што је знатно погоршало њену ионако тешку економску ситуацију, јер је изгубила градове Ужгород, Мукачево и Берегово, и плодну равницу. Због тога се аутор обраћа свим Русинима у Југославији с молбом да покажу своју националну свест и љубав према сународницима у Поткарпатској Русији, да се укључе у акцију РНПД прикупљања помоћи за своју браћу и помогну колико могу. Ту он наводи пример Словака из Бачког Петровца, који су прикупили и послали као помоћ својим сународницима у Словачкој око 80.000 динара. ${ }^{34}$ У истом броју РН објављен је преведен на русински језик апел владе Карпатске Украјине ${ }^{35}$ њеном становништву после после Бечке арбитраже и додељивања дела њене територије Мађарској. Влади Карпатске Украјине било је јасно да се одлука „великих“ мора поштовати и да није време за очајавање, него да треба да се сви прихвате посла у изградњи властите државе и боље будућности. Апел се завршава изражавањем наде да ће и они који су неправедно присаједињени туђој држави једног дана, по правди божјој, опет бити уједињени са својом браћом у једној држави. ${ }^{36}$ О ситуацији у Карпатској Украјини и Бечкој арбитражи говори се и у уводнику следећег броја РН. Наводи се да је Италија била спремна да се Мађарској преда цела Карпатска Украјина, али да Немачка то није дозволила. Ипак, аутор замера Немачкој да је „заборавила“ принцип по ком је, позивајући се на право народа на самоопредељење, одузела Чехословачкој Судетску област, а сада се није заложила да и Русини живе у једној држави. У истом чланку описани су догађаји од доласка на чело Карпатске Украјине А. Волошина, кога, како се наводи, подржава већина народа у држави. ${ }^{37}$ У истом броју РН преноси се део текста из београдских новина Време, у ком се углавном негирају навођења неких пољских новина о веома критичном стању у Поткарпатској Русији: да у њој не фукнционишу транспорт, телефони и пошта, да њен народ тражи плебисцит и жели да се изјасни за присаједињење Мађарској, као и тврдње да украјинска војска напада јединице чешке војске на својој територији. ${ }^{38}$ Даље се преноси кратка вест о Карпатској Украјини из Hrvatske straže, у којој се наводи да је Чешка дуго подржавала међу Русинима у Поткарпатској Русији русофилску струју, а на крају су ови показали своје право лице, када су се отворено приклонили мађарској политици и залагали се за присаједињење Поткарпатске Русије Мађарској. ${ }^{39}$

Када је у Чехословачкој 19. новембра 1938. године донет нови устав, у РН је објављена вест о томе са коментаром да по том уставу Чехословачка има заједничка министарства само за спољне послове, војску и финансије, а Поткарпатска Русија је добила потпуно иста права као и Словачка. Даље се наводи да званично име Поткарпатске Русије треба да одреди њен парламент, чије сазивање је најављено у

\footnotetext{
${ }^{34}$ Руски новини, 45/1938, 11. новембар, 1-2.

${ }_{35}$ Влада Чехословачке је 30. новембра 1938. године легализовала као алтернативно име за Поткарпатску Рус Карпатска Украјина (П. Р. Магочій, Нав. дело, 240).

${ }^{36}$ Руски новини, 45/1938, 11. новембар, 2.

${ }^{37}$ Руски новини, 46/1938, 18. новембар.

${ }^{38}$ Исто.

${ }^{39}$ Исто, 4.
} 
року од три месеца, и да реши питање службеног језика и наставног језика у школама. Поводом доношења новог чешког устава министар Ј. Ревај је преко чешког радија одржао поздравни говор. ${ }^{40}$ После тога следи текст „Карпатска Україна у нових гранїцох“, у ком се наводи да је 1/7 њене територије уступљена Мађарској, са укупно 181.609 становника, од тога 36.735 Русина, 86.681 Мађар итд., а у Карпатској Украјини је остало 535.748 становника, 410.181 Русин, 53.832 Јевреја, 22.719 Мађара, 8.341 Немац, 16.714 Чеха и Словака, укупно 19\% националних мањина. Наведени подаци су према чешкој статистици, а у најскорије време ће бити обављен нови попис становништва. ${ }^{41}$

После уступања Ужгорода, Мукачева и Берегова са широм околином Мађарској, седиште Мукачевске епархије нашло се у Мађарској, а гркокатолици у Поткарпатској Русији остали су без свог епископа. Света столица је доста брзо реаговала и 15. новембра за апостолског визитатора са правом администратора за гркокатолике у Поткарпатској Русији именован је крижевачки епископ др Дионисије Њаради. О томе он говори у интервјуу за Лавовске новине Новий час, а део тог интервјуа касније је пренет у РН. Ту епископ Д. Њаради наводи да, када је 3. новембра 1938. године у Риму сазнао о Бечкој арбитражи, схватио је да је око 400.000 гркокатолика у Карпатској Украјини остало без духовног пастира, јер је Ужгород, седиште Мукачевске епархије, припао Мађарској, и одмах је написао меморандум и предао га секретару Конгрегације за Источну цркву кардиналу Тисерану. На аудијенцији код папе 14. новембра епископ Д. Њаради је прво говорио о својој Крижевачкој епархији, а онда је папа почео разговар о решавању питања гркокатолика у Карпатској Украјини. После тога Д. Њаради је добио декрет о именовању за апостолског визитатора са правом администратора над гркокатолицима у Карпатској Украјини. Из Рима се прво вратио у Крижевце да заврши неке хитне послове и одмах је кренуо у Хуст. Ту је било око 400.000 верника гркокатолика и око 300 свештеника. Епископ Д. Њаради је прво морао да свима јасно стави до знања да је Апостолски престол одузео мукачевском епископу Александру Стојки јурисдикцију над гркокатолицима у Поткарпатској Русији, јер је Ужгород, где је било седиште Мукачевске епархије, прикључен Мађарској. ${ }^{42}$

Вест о именовању Д. Њарадија за апостолског визитатора и администратора над гркокатолицима у Карпатској Украјини одмах је била објављена у РН. Русини у Југославији били су веома поносни на свог епископа, пореклом из Руског Крстура, сматрајући да су му тиме указани велико поверење и част. ${ }^{43}$ Касније је у РН објављено писмо Д. Њарадија у ком описује да је стигао у Хуст, где има много посла, а мало радника. Наводи да би му тамо биле потребне једне новине као што су $\mathrm{PH}$, и један часопис за децу као Наша заградка ${ }^{44}$ коју издаје РНПД. ${ }^{45}$

\footnotetext{
${ }^{40}$ Руски новини, 47/1938, 25. новембар, 1.

${ }^{41}$ Исто, 2.

${ }^{42}$ Руски новини, 3/1939, 20. јануар, 1-2.

${ }^{43}$ Руски новини, 48/1938, 2. децембар.

${ }^{44}$ Нама заградка - часопис за децу који је издавало РНПД у периоду 1937-1941. године. Уредник је био учитељ и књижевник Михајло Ковач.

${ }^{45}$ Руски новини, 49/1938, 9. децембар, 3.
} 
Ујесен 1938. године у РН с поносом је истицано да ће Русини у Средњој Европи имати своју независну државу, а неретко је и пренаглашаван њен значај у међународним односима и њено значење за мир у Европи. Анонимни аутор у тексту "Своя власна держава“" истицао је да је од јесени Поткарпатска Русија у жижи интересовања у европској политици. Иако је реч о малој држави, односно федералној јединици у саставу Чехословачке, која није ни богата ни моћна, он сматра да она има велики значај у европској политици, јер многи у њој виде почетак ослобођења русинско-украјинског народа који има око 50 милиона и по бројности је трећи у Европи. Због тога је украјинско питање постало значајно. Ипак, аутор је свестан да је свима јасно да је украјинска држава са њеним сировинама, фабрикама и пољопривредним производима у интересу Немачке. Само једној словенској држави јако смета Поткарпатска Русија - Пољској, и она ради све да се њена територија прикључи Мађарској, јер се Пољаци плаше да ће постојање самосталне Поткарпатске Русије подстицати буђење Русина/Украјинаца у Пољској којих има око 10 милиона, и да ће и они кренути у борбу за своје ослобођење. На крају аутор констатује да многе стране новине већ пишу о томе да је после Чехословачке Пољска следећа у немачким плановима, и да се Немци у Пољској већ дижу. ${ }^{46}$ у истом броју РН пренет је део текста из београдских новина Време, у ком се наводи да је већ отпочела борба за слободу велике Украјине која ће запечатити судбину бољшевика, јер се догађаји у Карпатској Украјини развијају брзим темпом. Аутор сматра да је Немачка пропагандом украјинске државе отпочела политичке активности и планове за покрет на исток. ${ }^{47}$ После тога у РН пренети су делови текста објављеног у Времену, који преноси чланак из французких новина $L ' E v r$ у којима Андре Пјер пише: с правом се у Европи, узнемиреној многим националним питањима на дневни ред поново поставља украјински проблем, али сада снажније него после Првог светског рата. Наводи се да према украјинским статистикама Украјинаца има 43 милиона. Подељени су у 4 државе. Сматра се да у Совјетској Украјини има око 35 милиона становника, од тога 32 милиона Украјинаца. После рата Пољска је добила око 7 милиона Украјинаца. У Румунији, у Буковини и Бесарабији, има око милион Украјинаца и у Карпатској Украјини око 500.000. Украјинска држава, која би окупила све Украјинце, била би већа од Француске и по територији и по броју становника. Међутим, стварање независне украјинске државе је против интереса бољшевичке Русије, Пољске и Румуније. Чехословачка је била приморана да Украјинцима да широку аутономију у Карпатској Украјини. Украјинци у Пољској су највише угњетавани, јер Пољска ништа није испунила у вези са оним што је обећала Украјинцима после рата. Зато Украјинци оштро иступају у пољском парламенту за своју аутономију. ${ }^{48}$

У уводнику у РН од 23. децембра 1938. године под насловом „Швет и ми“ анонимни аутор наводи да је русинско/украјинско питање изашло на широко поље европске политике у вези са поделом Чехословачке. По њему, Чеси су дуго одбијали

\footnotetext{
${ }^{46}$ Руски новини, 50/1938, 16. децембар.

${ }^{47}$ Исто.

${ }^{48}$ Руски новини, 51/1938, 23. децембар, 4.
} 
да Поткарпатској Русији дају аутономију коју су јој обећали, али тек када је Мађарска у савезу са Пољском почела да све гласније захтева прикључење Поткарпатске Русије, 6. октобра 1938. године чешка влада је прогласила њену аутономију. ${ }^{49}$ Међутим, Чеси у почетку нису били искрени и добронамерни према Русинима и настојали су да владу Поткарпатске Русије саставе од људи који су били за разбијање јединства Русина. Тек када је постало очигледно да су ови фаворити чешке владе издајници, који су радили на прикључењу територије Поткарпатске Русије Мађарској, она је морала да промени своју политику и поставила је за премијера А. Волошина и друге чланове кабинета министара који стварно представљају Русине. ${ }^{50}$

У РН бија је објављена вест да је од 1. јануара 1939. године Поткарпатска Русија званично променила име у Карпатска Украјина, и да је украјински језик и службено проглашен за државни. ${ }^{51}$ Још у децембру 1938. године влада у Хусту донела је одлуку да се у школама у Карпатској Украјини уводи народни русинскоукрајински језик уместо дотадашње мртве мешавине русинског са руским и чешким. Ипак, тамо где се пријави бар 40 деце чији родитељи желе да њихова деца похађају школу на руском језику, биће отворено такво одељење, али ако број ученика падне испод 30 , одељење ће се затворити. ${ }^{52}$

У божићном броју РН преноси се текст из београдске Политике о почетку суђења А. Бродију, првом премијеру Поткарпатске Русије, за велеиздају, и доста опширно се описује његова сарадња са мађарским властима. ${ }^{53}$

Акција РНПД прикупљања помоћи за Карпатску Украјину настављена је и на почетку 1939. године. У РН у тексту „За нашу Горнїцу” РНПД позива Русине у Југославији да помогну својим сународницима у Карпатској Украјини, јер Русини/Украјинци на целом свету прикупљају за њих помоћ, само Украјинци у Пољској и у Совјетском Савезу то не смеју радити. Наводи се да ће ученици за Божић да „коледују“ и да тако прикупљају помоћ за Карпатску Украјину. Помоћ се може прикупљати у зрну и у новцу. На седници Главног одбора РНПД одлучено је да се у сваком русинском насељу оснује одбор за прикупљање помоћи за Карпатску Украјину. Ту се наводи да су Словаци у Југославији прикупили око 200.000 динара помоћи за Словачку. ${ }^{54}$ Прикупљање помоћи требало је да траје до 15 . фебруара. У РН су навођени подаци о томе колико су ученици по појединим местима прикупили на „коледовању“. 55

У РН 13. јануара 1939. године објављена је посланица епископа Д. Њарадија свештенству и верницима Карпатске Украјине, у којој он, између осталог, спомиње

\footnotetext{
49 На заједничком заседању Русинског народног већа у Ужгороду 8. октобра проглашена је аутономија Поткарпатске Русије, а влада у Прагу је потврдила њену владу 11. октобра, чиме је и формално признала њену аутономију.

${ }^{50}$ Руски новини, 50/1938, 16. децембар.

${ }^{51}$ Руски новини, 1/1939, 6. јануар, 2.

52 Руски новини, 51/1938, 23. децембар, 1.

${ }_{53}$ Руски новини, 1/1939, 6. јануар, 6.

${ }^{54}$ Руски новини, 2/1939, 13. јануар.

55 Руски новини, 4/1939, 27. јануар, 2.
} 
како је Божје провиђење учинило да он - потомак оних Русина који су пре 170 година напустили свој завичај испод Карпата и одселили се на југ, као архипастир тих Русина/Украјинаца у Југославији, који се увек интересовао за национални и верски живот своје браће/сународника у горњим крајевима - буде постављен за њиховог духовног пастира. ${ }^{56}$ У рубрици „Зос наших крайох“ у тексту под насловом „Карпатска Україна“ наводе се подаци о средњим школама у Карпатској Украјини: ради 6 гимназија, две препарандије и трговачка академија, а у тексту „Наш универзитет“ наводи се да из Прага треба да се пресели у Хуст Украјински слободни универзитет који тамо ради од 1922. године, и биће му придодат Богословски

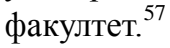

У РН у тексту „Нємецка помоц“ анонимни аутор анализира политичку ситуацију и намере Немачке да помогне стварању украјинске државе. Мада истиче да у политици нема љубави и да држава која помаже другој увек има у томе и неке своје разлоге и интересе. Доста наивно закључује да се не треба плашити да ће Немци покушати да од Украјине направе своју колонију, јер је могуће успоставити такве односе да свака држава има користи од међусобне сарадње. Сматра да је Украјина по својој територији већа од Немачке и да Немачка не би могла да је претвори у своју колонију. По њему, Немачкој као индустријској земљи, Украјина је потребна као земља која има пољопривредне производе и друге сировине, али и као земља у коју би пласирала своје индустријске производе. ${ }^{58}$ Очигледно, аутор текста је размишљао као у мирнодопска времена, као да није уопште није био обавештен о најновијим збивањима у Европи и о немачкој експанзионистичкој политици.

У току припрема за парламентарне изборе у Карпатској Украјини њена влада је 20. јануара 1939. године распустила све политичке партије, осим Немачке партије, и формирала јединствену организацију - Украјинско национално уједињење (Ванат 1985, 60). ${ }^{59}$ У РН тим поводом објављен је текст „Є Синство нашого народу на Горнїци 'Є Сен Бог, єден народ, єден вожд"' у ком се наводи да ће на парламентарним изборима бити само листа Украјинског националног уједињења (УНУ) на челу са премијером А. Волошином. Ту се наводи да су новине Нова свобода постале орган УНУ (РН 5/1939, 3. фебруар, 1). ${ }^{60}$ Сама чињеница да су пред парламентарне изборе забрањене све дотадашње политичке партије, осим немачке, да је формирана нова партија - Украјинско национално уједињење, и да је за изборе примљена само једна листа на челу са премијером А. Волошином, јасно указује на тенденције у правцу формирања тоталитарног режима у Карпатској Украјини. Слични политички процеси у то време одвијали се и у Словачкој, ${ }^{61}$ што је сасвим разумљиво када се зна да су се ове две аутономне области Чехословачке - Словачка и Карпатска Украјина, у процесу проглашења властите независности највише ослањале на Немачку.

\footnotetext{
${ }^{56}$ Руски новини, 2/1939, 13. јануар, 2.

${ }^{57}$ Исто, 3.

${ }^{58}$ Руски новини, 4/1939, 28. јануар, 1.

${ }^{59}$ I. Ванат, Нариси новітньої історії украйнців Східної Словаччини II (1938-1948), 60.

${ }^{60}$ Руски новини, 5/1939, 3. фебруар, 1.

${ }^{61}$ Dušan Kovač, Istorija Slovačke, Novi Sad 2012, 300.
} 
После парламентарних избора у РН објављени су резултати: за листу УНУ гласало је 264.000, односно 92,40\% од укупног изашлих на изборе. У тексту се констатује да су резултати избора показали пред целим светом коме народ верује, а издајници, који су се оријентисали на Москву или на Будимпешту, нису добили народно поверење. Изборе је пратило у Хусту око 20 страних новинара, који нису имали примедбе на њихову регуларност. ${ }^{62}$ У следећој вести наводи се да су Русини/Украјинци у Америци организовали прикупљање помоћи за Карпатску Украјину у одећи и новцу. Поред тога, русинско/украјинске организације у САД одлучиле су да подигну кредит од банака у вредности од 5 милиона долара за помоћ влади у Хусту за изградњу железница и путева. ${ }^{63}$

После парламентарних избора власти у Прагу су одлагале сазивање парламента Карпатске Украјине, што је у РН прокоментарисано као настојање владе Чехословачке да не изгуби могућност контроле и мешања у послове Карпатске Украјине. У тексту се даље наводи шта све треба да уради новоизабрани парламент: да прогласи слободу и самосталност КарпатскеУкрајине, да прогласи њено званично име: Карпатска Украјина, да спроведе аграрну реформу, да обезбеди сиромашно становништво најнеопходнијим намирницама, да уреди разумно искоришћавање природних богатстава и да се побрине да Карпатска Украјина има већу туристичку мобилност. ${ }^{64}$

На почетку 1939. године догађаји у Карпатској Украјини и око ње одвијали су се све брже тако да у РН, које су излазиле недељно, нису могли бити пропраћени и прокоментарисани сви важнији догађаји. У РН од 17. марта већ се описују трагични догађаји у Карпатској Украјини. Када је сазнао да ће Словачка прогласити своју независност, А. Волошин је 14. марта најавио да ће и Карпатска Украјина прогласити независност и формирао је нову владу. Нови министар иностраних послова J. Ревај сазвао је за 15. март заседање парламента. Проглашењем независности Словачке 14. марта 1939. године означен је распад Чехословачке, а Мађарска је истог дана кренула са својим војним снагама на границе Карпатске Украјине. Премијер Волошин је 15. марта молио Хитлера да Немачка прими Карпатску Украјину под свој протекторат, да би је на тај начин заштитио од напада Мађарске, али одговор није стигао. ${ }^{65}$

На свом првом заседању 15. марта парламент Карпатске Украјине једногласно је прогласио њену независноста, а за председника државе изабран је А. Волошин. Донета је одлука да је украјински службени језик Карпатске Украјине, да њена застава буде национална украјинска плаво-жута застава, и да њен грб буде трозуб, грб из времена Кијевске Русије. ${ }^{66}$ Парламент Карпатске Украјине заседао је 15. марта под претњом артиљерије мађарске окупационе војске која је продирала према Хусту. Истог дана увече председник А. Волошин заједно са члановима владе

\footnotetext{
${ }^{62}$ Руски новини, 7/1939, 17. фебруар.

${ }^{63}$ Исто, 1.

${ }^{64}$ Исто.

${ }^{65}$ Руски новини, 11/1939, 17. март.

${ }^{66}$ Міністерство закордонних справ України, Уряди Карпатської Украӥни, Слово - Науково-літературний і культурологічний часопис, 1, Кула 2008, 97-98.
} 
морао је да пред мађарском војском емигрира у Румунију. Из Румуније А. Волошин је прешао у Краљевину Југославију, где је боравио неколико дана. ${ }^{67}$ У РН објављена је вест да се А. Волошин 22. марта на путу из Београда у Загреб заједно са министром др Штефаном и са својим секретарем зауставио у Шиду да би се сусрео са ондашњим Русинима и том приликом је говорио о ситуацији у Карпатској Украјини. Сутрадан је одслужио службу и кренуо даље за Загреб. ${ }^{68}$ Из Загреба А. Волошин је отпутовао у Берлин ${ }^{69}$ а у мају је прешао у Праг, где је остао до марта 1945. године, и где су га органи службе безбедности СССР-а ухапсили и одвезли у Москву. Умро је у Бутирском затвору 19. јула 1945 . године. ${ }^{70}$

После окупације Карпатске Украјине од стране Мађарске у РН су објављивани прилози о херојској борби војске и народа против окупатора. Често су преношене вести и из иностраних извора да би се указало да се „цео свет диви“ малом и ненаоружаном народу који храбро брани своју земљу од 20 пута јаче мађарске војске. Због тога, сматра аутор, Карпатска Украјина заслужује славу, коју су пре рата имале Србија и Црна Гора. Ту се наводи и вест коју је пренео француски радио у Стразбуру, да Европа није довољно ценила Карпатску Украјину, и да је народ који су издали и Чеси и Хитлер, и који се храбро борив против окупатора, заслужио да му се у тој борби помогне. У другој вести о Карпатској Украјини наводи се да Чеси не само да су издали Карпатску Украјину већ су и своју државу без борбе предали Немачкој. ${ }^{71}$

Када су мађарске снаге заузеле Карпатску Украјину, окупационе власти одмах су забраниле деловање епископа Д. Њарадија. Сведочење секретара епископа Д. Њарадија о томе објављено је у Hrvatskoj straži и касније је пренето и у Русинским новинама под насловом "Як Мадяре поступовали зос нашим владиком Преосв. Нярадийом". ${ }^{72}$ Ту се наводи да је мађарска војска 16 . марта послеподне ушла у Хуст, а 18. марта (четвртак) код епископа су дошли војници с бајонетима на пушкама и саопштили му да је интерниран у својој резиденцији до даљњег. Није могао да излази, нити је било ко магао да долази код њега, чак ни његов секретар. Војници с бајонетима на пушкама даноноћно су били поред њега. Нису му

\footnotetext{
${ }^{67}$ Аугустин Волошин је био примљен у Југославији као председник суверене државе, вид.: Микола Вегеш, Володимир Задорожний, Карпатська Україна 1938-1939 рр. у світлі європейської періодики, Карпатска Україна і Августин Волошин (Матеріали міжнародної наукової конференції "Карпатська Україна - пролог відродження української дерави”, Ужгород, 11-12 березня 1994 року), Ужгород 1995, 48-60.

${ }^{68}$ Руски новини, 13/1939, 31. март, 3.

${ }^{69}$ Руски новини, 15/1939, 14. април, 1.

${ }^{70}$ Міністерство закордонних справ України, Уряди Карпатської Украӥни, 111.

${ }^{71}$ У РН су, не рачунајући новине из Поткарпатске Русије / Карпатске Украјине, веома ретко преношене вести о Карпатској Украјини из других страних новина, и то углавном посредством југословенских новина. А у том периоду вести и прилози о догађајима у Поткарпатској Русији / Карпатској Украјини у другој половини 1938. и на почетку 1939. године били су често на страницама штампе у Енглеској, Француској, Италији, Пољској, Мађарској, Румунији, Југославији, Шведској и у другим земљама, али само у Пољској и Мађарској о њој је увек писано у негативном контексту (М. Вегеш, В. Задорожний, Нав. дело).

${ }^{72}$ Опширније о томе у раду Михајла Малацка: Михайло Маляцко, Преосвященний владика Д-р Діонізій Няраді-апостол і місіонер, Богословія, т. 59, Рим 1995, 147-193.
} 
дозволили чак ни у недељу да служи службу. Касније су ипак дозволили да код епископа дође његов секретар и да служе у епископској капели, али и ту је војник с бајонетом на пушци непрекидно мотрио. Војне власти нису хтеле да наређење издају написмено и уверавале су епископа да је слободан и да не дирају у његову јурисдикцију, а епископ није могао да ступи у контакт са својим свештенством и верницима.

У среду (22. марта) код епископа је дошао жандармеријски капетан и саопштио му да министар вера Гоман Балинт жели да разговара с њим и да је наредио да епископ под полицијским надзором дође код њега у Будимпешту. Епископ је тражио писмено наређење, али га није добио и изјавио је да неће никуд да иде без свог секретара, и молио је да му се дозволи да посвршава неодложне послове као апостолски визитатор. Саопштено му је да ако се не одазове добровољно на позив министра, биће одведен силом. Послеподне је стигао телеграм наводно из Министарства вера у ком је стајало да се дозвољава да епископ дође у Будимпешту са својим секретарем, али и да може да посвршава неке послове и да служи службу. У петак је жандармерија дошла колима и одвезла је епископа из Хуста преко Њиређхазе, Дебрецина и Солнока у Будимпешту. Када су увече стигли испред Министарства вере, министар је рекао да он није позвао епископа и да нема шта с њим да разговара. Епископ Њаради је одмах отишао у Апостолску нунцијатуру и био је примљен. Тек у суботу (25. марта) министар вера је примио епископа Њарадија, а у разговору је настојао да скине са себе одговорност због лошег поступања жандармерије са њим. Из Будимпеште епископ Њаради је отпутовао у Крижевце, а после је у Рим, да као апостолски визитатор поднесе извештај о свом раду у Карпатској Украјини. ${ }^{73}$

О насилничком понашању мађарских окупационих власти према гркокатоличком епископу и свештеним лицима, и цивила и униформисаних људи, војске и полиције, сведочи у својим сећањима и монах Степан-Севастијан СаболЗореслав. Он описује како се нашао у канцеларији епископа Д. Њарадија када је један мађарски цивилни службеник викао на епископа као на кочијаша, а пошто је боље од епископа знао мађарски, опоменуо је тог службеника да не сме тако да се понаша према католичком епископу. Овај се веома наљутио, лупио вратима и отишао. После пар дана по Сабола су дошли мађарски жандари и прво га одвели у затвор а после депортовали ван граница Карпатске Украјине. ${ }^{74}$

Када су 14. марта 1939. године мађарске окупационе снаге кренуле на Карпатску Украјину, у њој је проглашена општа мобилизација. Дирекција позоришта „Нова сцена“ у Хусту сазвала је 15. марта ујутру цео ансамбл и обавестила га да позориште силом прилика престаје да ради. Неки чланови „Нове сцене“ после извесног времена стигли су преко Румуније у Југославију. Како наводи Јуриј Шерегиј, директор позоришта и режисер, он је на позив пароха у Руском Крстуру и уредника РН дошао у Крстур почетком априла, где је већ било неколико чланова

\footnotetext{
${ }^{73}$ Руски новини, 13/1939, 31. март, 3.

74 Наталка Ребрик (ур.), О. Степан-Севастіян Сабол (Зореслав), Шкільна серія, випуск 3, Гражда, Ужгород 1998, 22-23.
} 
овог позоришта и известан број других емиграната из Карпатске Украјине. Ту је Ј. Шерегиј са члановима свог ансамбла из Хуста и крстурским аматерима до новембра, када је прешао у Шид, режирао неколико позоришних комада из класичног украјинског репертоара и имао са њима десетак наступа, у селу, другим местима па чак и у професионалном позоришту у Осјеку. ${ }^{75}$

Михајло Фирак, уредник РН, у прегледу догађаја у 1938-1939. години у РК дао је кратак преглед о Поткарпатској Русији од стицања аутономије до проглашења њене независности и пропасти у марту 1939. године, а на крају наводи да је око 200 емиграната из Карпатске Украјине, претежно интелигенције, нашло уточиште у Руском Крстуру, где су их сународници веома лепо примили, а онда су се разишли тражећи место привременог или сталног боравка по разним европским земљама. ${ }^{76} \mathrm{O}$ прихватању у Р. Крстуру око 200 емиграната из Карпатске Украјине оставио је запис књижевник Михајло Ковач. Он наводи да су се власти из Београда обратиле телефоном пароху у Р. Крстуру М. Фираку, уреднику РН, и питале га да ли Р. Крстур жели да прими на своју одговорност око 200 емиграната из Карпатске Украјине који су били на границе између Румуније и Југославије и да ли може да им привремено обезбеди смештај и храну. Југославија је хтела да остане неутрална и није хтела да прими емигранте на себе. Село је прихватило емигранте. Чак је било организовано прикупљање хране за њих и по другим местима где су живели Русини. ${ }^{77}$

На крају закључак: у другој половини 1838. и у прва три месеца 1939. године у РН објављиване су бројне вести, прилози, коментари и чланци о Поткарпатској Русији и Карпатској Украјини, који су својим садржајем информисали Русине у Југославији о збивањима у њиховом старом завичају. Ови текстови имали су значајан утицај на подизање националне свести код Русина у Југославији и на јачање осећања припадности русинско/украјинском народу који живи са обе стране Карпата, чему сведоче како акције организовања прикупљања помоћи међу Русинима у Југославији за своју браћу у Карпатској Украјини, тако и прихватање у Р. Крстуру око 200 избеглица из Карпатске Украјине после њене окупације од стране Мађарске.

\footnotetext{
${ }^{75}$ Юрій Шерегій, Нарис історії українських театрів Закарпатської Украӥни до 1945 року, Записки Наукового товариства ім. Шевченка, Історично-Філософічна Секція, том 218, Нью-Йорк - Париж -Сідней - Торонто - Пряшів - Лівів 1993, 322-324.

${ }^{76}$ Михайло Фирак, Огляд подййох у швеще за 1938-1939 рок, Руски календар 1940, Руски Керестур 1939, $181-182$.

${ }_{77}^{77}$ Михайло Ковач, Березнева ніч (Біженці із Карпатської Украӥни в Руському Керестурі), Карпатска Україна і Августин Волошин (Матеріали міжнародної наукової конференції "Карпатська Україна - пролог відродження української дерави”, Ужгород, 11-12 березня 1994 року), Ужгород 1995, 323-327.
} 


\section{Извори и литература:}

Ванат, Іван, Нариси новітньої історії украӥнців Східної Словаччини II (1938-1948), Пряшів $1985,353$.

Ванат, Іван, Нариси новітньої історії украӥнців Східної Словаччини I (1918-1938), Пряшів 1990, 408.

Вегеш, Микола - Задорожний, Володимир, Велич і трагедія Карпатської України, Ужгород 1993.

Вегеш, Микола - Задорожний, Володимир, Карпатська Україна 1938-1939 рp. у світлі європейської періодики, Карпатска Україна і Августин Волошин (Матеріали міжнародної наукової конференції "Карпатська Україна - пролог відродження української дерави”, Ужгород, 11-12 березня 1994 року), Ужгород 1995, 48-60.

Kovač, Dušan, Istorija Slovačke, Novi Sad 2012.

Ковач, Михайло, Березнева ніч (Біженці із Карпатської Украӥни в Руському Керестурі), Карпатска Україна і Августин Волошин (Матеріали міжнародної наукової конференції "Карпатська Україна - пролог відродження української дерави", Ужгород, 11-12 березня 1994 року), Ужгород 1995.

Магочій, Павло Роберт, Формування національної самосвідомості: Підкарпатська Русь (1848-1949), Ужгород 1994.

Маляцко, Михайло, Преосвященний владика Д-р Діонізій Няраді - апостол $i$ місіонер, Богословія, т. 59, Рим 1995.

Маркусь, Василь, Еволюиія політично-правового статусу Карпатської України в 1938-1939 роках, Карпатська Україна і Августин Волошин, (Матеріали міжнародної наукової конференції "Карпатська Україна - пролог відродження української держави" (Ужгород, 11-12 березня 1994), Ужгород 1995.

Міністерство закордонних справ України, Уряди Карпатської Украӥни, Слово - Науковолітературний і культурологічний часопис 1, Кула 2008, 77-111.

Паплацко, Велемир, Формованє и тратедия Карпатскей України, Карпатська Україна і

Августин Волошин, (Матеріали міжнародної наукової конференції "Карпатська Україна пролог відродження української держави” (Ужгород, 11-12 березня 1994), Ужгород 1995, 276-283.

Ребрик, Наталка (ур.), О. Степан-Севастіян Сабол (Зореслав), Шкільна серія, випуск 3, Гражда, Ужгород 1998, 88.

Руски новини, 1938-1938, Руске народне просвитне друштво, Руски Керестур

Фирак, Михайло, Оаляд подїйо у швеще за 1938-1939 рок, Руски календар 1940, Руски Керестур, 1939, 169-183.

Цап, Микола М., Тема Карпатскей Украӥни у периодичних и кнїжкових виданьох Руснацох и Українцох Югославиї, Карпатська Україна і Августин Волошин, (Матеріали міжнародної наукової конференції "Карпатська Україна - пролог відродження української держави" (Ужгород, 11-12 березня 1994), Ужгород 1995, 310-314.

Шандор, Вікентій, Спомини, т. I, Гражда, Ужгород 1996.

Шерегій, Юрій, Нарис історії украӥнських театрів Закарпатської Украӥни до 1945 року, Записки Наукового товариства ім. Шевченка, Історично-Філософічна Секція, том 218, Нью-Йорк - Париж - Сідней - Торонто - Пряшів - Лівів 1993. 


\title{
THE RUTHENIAN NATIONAL EDUCATIONAL SOCIETY AND RECEPTION IN SUBCARPATHIAN RUS'/CARPATHO-UKRAINE IN PUBLICATIONS FROM 1938 TO 1939
}

\begin{abstract}
Summary
According to the Peace Treaty signed in Saint Germain in 1919, Czechoslovakia was under the obligation to give autonomy to the Subcarpathian Rus', but it was only after signing the Munich Agreement in 1938 that the essential autonomy was achieved. The first Ministerial Office (the Cabinet of ministers) of the Subcarpathian Rus' was formed in October of 1938. The Ruthenian National Educational Association in its editions carefully monitored the situation in Czedhoslovakia, that is in the Subcarpathian Rus'. The Ruthenian Newspaper (Ruski novini) published the news, comments and additions on the events in the Subcarpathian Rus', which, on one hand, gave the Yugoslav Ruthenians enough information on the political, cultural, national and economical circumstances in their old homeland. On the other hand, the revival and strengthening of the Ukrainian national idea in the Subcarpathian Rus'/Carpathian Ukraine induced the strengthening of the national consciousness of the Yugoslav Ruthenians who started giving help to the refugees who came to Ruski Kerestur from the Carpathian Ukraine after its collapse in the March of 1939.
\end{abstract}

Keywords: Czechoslovakia, the Subcarpathian Rus'/Carpathian Ukraine, Ruthenians, Ukrainians, the Ruthenian National Educational Association, The Ruthenian Newspaper (Ruski novini), Augustyn Voloshyn. 